\title{
DAĞLARLA BOY ÖLÇÜŞEN ADAM
}

\author{
Yrd. Doç. Dr. Cahit EMRE*
}

Öyle insanlar vardır ki, yalnızca o dönemlerin temsilcisi olmakla kalmazlar, onlar aynı zamanda uğraşlarının da örneksel bir temsilcisi olurlar. Bu ozzellikleriyle onlarla ilgili pek çok olay kuşaklar boyu anlatılır durur. Ózellikle günümüz gibi yalnızca genel topumsal değerlerin değil, uğraşsal değerlerin de olağanüstü bir hızla aşındı̆̆ı, değerler karmaşasının yaşandığı dönemlerde, uğraşların sonsuza değin korunması gereken kimi değerleri ancak bu ömek insanlann yaşamlanındaki ayrıntularda bulunabilir. Işste Cemal Hoca, bu insanlardan biriydi, onun yaşantısının birkaç kişi arasında kalan küçük ayrıntılanında, yalnızca bugünkü bilim adamlanının değil, gelecek kuşakların da ơmek alması gereken pek çok değer gizlidir. Bugün bu değerlerin birer birer elimizden kayışını gördükçe, Hoca'ya duyduğum özlem kimi zaman katlanılmaz boyutlara ulaşıyor.

Yıllar once, Cemal Hoca'nın asistanı olmak için sınava girdiğimde, pek çok kişi Hoca'nın çok titiz olduğunu belirterek "ne yaptığının farkında mısın?" diyerek beni vazgeçirmeye çalışmışı, sanki titizlik, yaptuğı işe gereken önemi vermek, her zaman, her koşulda birinci sınıf iş yapmanın peşinde olmak, denkserlikten odün vermemek, uğraşının saygınlığı söz konusu olduğunda ödünsüz olmak, boyun eğmemek kơtü, kaçınılması gereken bir özellikmiş gibi. Çevremdeki insanlanı bu uyarılanı bana doğru yolda olduğumu gősteriyordu aslında. Cemal Hoca ile birlikte çalışuğım on iki yıl da ilk günkü adımımın doğruluğunun kanıt oldu. Cemal Hoca ile asistanı olmadan önce kişisel bir tanışıklığımız yoktu. 1984 Eylülünde kendisine sunduğum daktilo edilmiş Yüksck Lisans tez ơnerimi okuduktan sonra "iyi ki bizim alanda araştırma görevlisi oldun," dediği anda aramızda kurulan sıcacık sevgi köprüsü hala sapasağlam ayakta. Bu sözden sonra ilk özel ögrencesini verdi: "Daktilo ile yazarken noktalama işaretlerinden sonra bir ara vermek gerekir. Bundan sonra buna dikkat edersin." dedi. Bundan sonra Hoca'dan o kadar çok şey őgrendim ki, bunlan yalnızca alt alta sıralasam bile sayfalarca uzunluğunda bir dizeige olurdu. Hocanın anısına çıkarılan Armağan'da yer alacak bu yazıda bunlardan yalnızca küçük bir bőlümünü, bzellikle oğretim üyeliği uğraşının yukarıda sőzünü ettiğim ana değerine ilişkin olanları uğraşdaşlarımla paylaşmak amacıyla burada anacă̆ım.

Birlikte çalıştığımız on iki yıl içinde Hoca'yla hemen her gün görüşürdük. Birkaç gün görüşmediğimiz dönemlerde ise, ya Hoca ya da ben bir vesile yaratmaya çalışırdık. Bu görüşlerin hemen hepsi benim için başlı başına bir öğrenceydi. Bu görüşmelerimizde

* A.U. Siyasal Bilgiler Fakúltesi Kamu Yönetimi Oğretim Ưyesi. 
Hoca her zaman "iki uğraşdaşın sohbeti" havasını ustalıkla yaraurdı. Son yıllarda kendini verdił̧i dil çalışmalanyla ilgili olarak çeşitli alanların uzmanlarıyla yaptığı telefon göriłşmelerini ozellikle benim yanımda yaparak, o görüşmelerden bir şeyler ợrenmemi saźladı. "Dur, ... beyi senin yanında arayayım" derdi.

Her zaman gerçeğin ayrıntıda gizli olduğunu söyler, araşurmacılı̆̆ı, bilim adamlı̊̆ını iğne ile kuyu kazmaya, keçiboynuzundan bal çıkarmaya benzetirdi. Bir araşurmacının derlediģi bilgiler arasından gerçeği görebilme becerisine sahip olması gerektiğini her fursatta anımsatırdı. Ortak bir çalısmamız sırasında derlediğimiz yüzlerce bilgi arasında o gerçeği bulduğumuz zaman duyduğumuz büyük mutluluğun ikimizin de yüzüne yansıdığı bir anda sőyledił̣̆ "Cahit'ciğim şu anki mutluluğumazu hayali ihracatçılar hiçbir zaman tadamayacaklar" sözünü hiç unutamıyorum.

Hoca yalnızca işimizle ilgili bilgiler vermezdi, bir bilim adamının, bir oğretim üyesinin sahip olması gereken ana değerlerle tutumlar konusunda da sürekli olarak eğitirdi bizi. Bir oğretim üyesi olarak yapuğı her türlü değerlendirmede (sınavlar, tezler vb.) nesnellikle denkserlikten hiçbir zaman ayrılmadı. Üniversitenin çalkantılar içinde bulunduğu dönemlerde "sağdan soldan" gelen çeşitli etkileme çabalarına hiçbir zaman geçit vermedi. Kendisi hep birinci sınıf iş yapma çabasında olduğu için, birinci sınıf iş yapan kim olursa olsun, onun hakkında ne sőylenirse sőlensin hakkını teslim ederdi; kişisel olarak o kişiden hoşlanmazsa bile. Kơtü bir çalışma ya da sınav kağı̀dı ile ilgili değerlendirmesi de yine aynı nesnellik, aynı denkserlik anlayışıla olurdu. Hoca'nın elinde oylesine hassas bir terazi vardı ki, kimse hak ettiğinin ne bir gram fazlasını, ne de bir gram eksiğini alırdı. Hoca bunu kimi zaman tek başına kalmayı, sevimsiz, aksi bir hoca görüntüsü vermeyi göze alarak yapardı. Ögrencileriyle kendisinin arasına hiç kimsenin girmesine hiçbir zaman izin vermezdi.

Bir bilim adamının her şeyden önce kafasının aydınlık, ozzgür olması gerektiğini soylerdi. Bilim adamının iktidar sahipleri karşısında eł̆ilmesini hiçbir zaman doğru bulmadı. Bir bilim adamı ülke sorunları üzerinde yapı̆̆ı çalışmalarıa ilgili olarak erktekilerle görüşebilirdi, ancak bu tür iliş̧kilerde saygınlı̆̆ına halel getirecek bir davranış içinde olamazd. Düşünce ozgürllügünü koruyabilmenin en onemli koşulu, erk sahipleri karşısında ya da başkaları karşısında kendini borçlu hissetmemek, doğruları çekinmeden dile getirebilme gücünü elinde tutmaktu. Bu nedenle o, erktekilerden hiçbir zaman kendisini ileride güç durumda bırakabilecek hiçbir şey istemedi. Bir akşam TV haberlerinde dönemin YÖK Başkanının Cumhurbaşkanı karşısında yerlere kadar eğilmesi, Cumhurbaşkanının ağzından çıkan her sözü onaylaması karşısında çok sinirlenmiş, şunları sơylemişti: "ABD'de iken bir kamu binasının -büyük bir olasılıkla mahkeme binası idi- girişinde "bana dağlarla boy ölçüşecek adamlar getirin" yazıyordu. Bu adamlar köstebek yuvalarıyla bile boy olçüşemezler." Dersimi almışım; "bir bilim adamı dağlarla boy ölçüşebilmelidir." O'nu yitirdikten sonra Hoca'nın yaşantısını gözümün ơnünde canlandırdığımda, onun gerek bilim adamı, gerck ŏgretim üyesi olarak, ana değerlerle ilgili odünsüz tutumunun ardında hep "dağlarla boy ólçüşen adam olma" ülküsünün yatuğını düşündüm. Bu ülküsüne ulaşmışı da, o gerçekten de dağlarla boy ölçüşen bir adamdı. Hoca'yı her düşündügümde aklıma hep bu sőzün gelmesi, sanırım onu en iyi anlatan sözlerin bunlar olmasındandır.

Hoca'nın Türk dilinin arılaştunlmasıyla ilgili çalışmalarının alunda da bu ülkünün yattuğını düşünüyorum. Bir bilim adamı, kendi anadiliyle bilim yapabilmeliydi. Yıllarca yabancı ülkelerde yaşamış bir insanın bile kendi anadiliyle düşündüğü gerçeğinden yola 
çıkarak, "bilimsel düşüncenin temeli olan kavramlar, terimler" kendi anadilimizde olmadıkça bilimsel gelişmemizin yeterli bir hızda olamayacağına inanırdı. Dilimizin ozzleşmesiyle ilgili inanılmaz tutkusunun ardındaki düşünce de buydu. Türkçe'nin bilim dili olarak en soyut terimleri bile karşılayacak gụ̈te olduğunu, Kamu Yönetimi cevirisinde kanıtladı da. Bu konudaki aymazlıklarla, haksız suçlamalarla bas etmenin en iyi yolunun yabancı terimlere karşılık bulma işini nasıl yapư̆ını anlatmak olduğunu düşündü. Bu alanda da Öncülük yapt, Sözcüklerin Oyküsü'nü yazdı. Yaşama gözlerini yummasından birkaç ay önce kitabın yayımlanmış olması onu bir yandan çok mutlu etmiş, రbür yandan hüzünlendirmiş̧i; çünkü Kültür Bakanlığına 1992 yılında yayımlanmak üzere verdiği Türk Hekimlik Dili* henüz yayımlanmamışı, yine yıllanını verdiği Sözlük fiş̧lerde kalmışt. Türk Hekimlik Dịli bitmiş bir çalışmaydı; nasılsa yayımlanırdı, ya Sözlük? Son görüşmelerimizde "Mıhçıŏglu Sözlüğ̈ü" adını verdiği Sőzlüğün fişlerden bilgisayara aktarılması, son denetimlerinin yapılarak yayıma hazırlanması işini de bana bırakmıştı. Onun oğrettiği, yaşamıyla gosterdiği ana değerlerden ayrılmadan, bize bıraktıklarını daha ileriye taşımanın yanında, yirmi yılını verdił̆i Sözlüğünü yayıma hazırlamak Hocama ơdemem gereken bir gönül borcumdur.

Bir bilim adamı, bir oğretim üyesi olarak odün vermez görüntủsünün ardında sıcacık, duyarlı, alıı gibi insanın yautı̆ını söylemek, onu yakından tanıyan insanlar için ilgi çekici bir şey olmasa gerek. Hoca'nın bu yönünü çok çeşitli vesilelerle görme, bu anlamda pek çok şeyi paylaşma mutluluğuna eriştim. Bu vesilelerden biri de, 1987 yılında ÖSYM Temsilcisi olarak, çocukluğunun geçtiği Artvin'e yapuğı geziden sonra kaleme aldığı "Anneme Mektup"tu. Geziden sonra bir hafta boyunca odasina kapanıp daktilo ettiği yazıda hem Türkiye'nin Cumhuriyetin ilk yıllanyla bugününün çarpıcı bir karşılaşurmasını, hem de iç sızlatan "insan manzaraları"nı bulmak olanaklıdır. Hele bir "Ali Faik Olayı" var ki... Hoca bu yazıyı daktilo ederken beni odasına çağırır kimi bölümlerini bana okurdu. Daha bir ortaokul oğrencisiyken, takıldığı yoksul, okuldan sonra gügümle süt taşımak zorunda olan sınıf arkadaşı Ali Faik'in "Bu güğümlerin alunda nasıl büyüyelim Cemal" yanıu ikimizin de yüreklerini ürpetti; göz yaşlanna boğulduk. Bu da insanca duyarlıklan olmayanların hiçbir zaman yaşayamayacaklan bir duyguydu. Bu yazının bir başka özelliği, Hoca'nın bilimsel yazılanı dışındaki yazılarında da ne denli güçlü bir biçeminin olduğunu göstermesi. Bu güzel yazı da, sağlığında çok istediği halde yayımlanamamışu. Armağan'da Hoca'nın bir başka yơnünü bize anlatan bu yazıya da yer verdik."

Iki yıl önce aramızdan ayrıldığında Hoca'nın, gidişini bir ayrılıs olarak görmediğimi, hep yanımızda olacağını sőylemiştim. Onsuz geçen iki yılda o hep yanımızda oldu, yolumuzu aydınlatı, hep de oyle olacak. Ancak her geçen gün onun yokluğu bir başka dokunuyor yüreğimize. Hocam çok özlüyoruz sizi.

** Türk Hekimlik Dilli. Hoca aramızdan aynldıktan 1,5 yıl sonra, bu yılın başlarında Kültür Bakanlığınca yayımlanmıştır.

*** Hoca'nın değerli eşi Nurten Hanıma, focukları Umut'a, Elife, Cem'e bu yaziyı bizimle paylaştıklan için burada bir kez daha teşekkür ediyorum. 